Part of Journal of Research of the National Bureau of Standards, Volume 36, February 1946

\title{
EFFECT OF SOME ADDED MATERIALS ON DICALCIUM SILICATE
}

\author{
By Edwin S. Newman and Lansing S. Wells
}

ABSTRACT

Studies of binary systems are helpful in the investigation of polycomponent systems forming industrial products, such as portland cement, dolomite refractories, or blast-furnace slags. Details are given of the application of differential heating and cooling curves to the determination of the temperature of the $\alpha \leftrightarrows \beta$ inversion of $2 \mathrm{CaO} . \mathrm{SiO}_{2}$ in binary mixtures with $\mathrm{CaO}, \mathrm{SiO}_{2}, \mathrm{Al}_{2} \mathrm{O}_{3}, \mathrm{MgO}, \mathrm{Fe}_{2} \mathrm{O}_{3}$, $\mathrm{CaF}_{2}, \mathrm{TiO}_{2}, \mathrm{BaO}, \mathrm{Cr}_{2} \mathrm{O}_{3}, \mathrm{~B}_{2} \mathrm{O}_{3}, \mathrm{Mn}_{2} \mathrm{O}_{3}, \mathrm{~V}_{2} \mathrm{O}_{5}, \mathrm{P}_{2} \mathrm{O}_{5}, \mathrm{Na}_{2} \mathrm{O}$, and $\mathrm{K}_{2} \mathrm{O}$. These added materials, excepting $\mathrm{CaO}$, lowered the temperature of the $\alpha \rightleftarrows \beta$ inversion and estimates of the limits of solid solution in $\alpha-2 \mathrm{CaO} . \mathrm{SiO}_{2}$ are given. X-ray patterns of $\beta-2 \mathrm{CaO} . \mathrm{SiO}_{2}$ containing $\mathrm{BaO}, \mathrm{P}_{2} \mathrm{O}_{5}, \mathrm{Na}_{2} \mathrm{O}$, or $\mathrm{K}_{2} \mathrm{O}$ indicated the existence of solid solutions of the substitution type. Observations were made of the effectiveness of the added materials in preventing dusting, which results from the $\beta \rightarrow \gamma$ inversion of $2 \mathrm{CaO} . \mathrm{SiO}_{2}$. It was found that $\mathrm{Mn}_{2} \mathrm{O}_{3}$ should be added to the list of known chemical inhibitors of dusting.

\section{CONTENTS}

I. Introduction

II. Materials and general procedure for preparing and testing mixtures.. 139

III. Choice of the method of differential heating curves_.............. 140

IV. Apparatus and procedure for obtaining differential heating and cooling curves _. 141

V. Temperature of the $\alpha \rightleftarrows \beta$ inversion of $2 \mathrm{CaO} . \mathrm{SiO}_{2}$

VI. Effect of added materials on $2 \mathrm{CaO} \cdot \mathrm{SiO}_{2}$

1. $\mathrm{Al}_{2} \mathrm{O}_{3}, \mathrm{MgO}, \mathrm{Fe}_{2} \mathrm{O}_{3}, \mathrm{TiO}_{2}$, and $\mathrm{CaF}_{2}$

2. $2 \mathrm{BaO} \cdot \mathrm{SiO}_{2}$ and $\mathrm{BaO}$

3. $\mathrm{Cr}_{2} \mathrm{O}_{3}$

4. $\mathrm{V}_{2} \mathrm{O}_{5}, \mathrm{P}_{2} \mathrm{O}_{5}, \mathrm{~B}_{2} \mathrm{O}_{3}$, and $\mathrm{Mn}_{2} \mathrm{O}_{3}$

5. $\mathrm{Na}_{2} \mathrm{O}$ and $\mathrm{K}_{2} \mathrm{O}$

VII. X-ray diff raction patterns

VIII. $\mathrm{B} \rightarrow \gamma$ inversion of $2 \mathrm{CaO} . \mathrm{SiO}_{2}$

IX. Summary and conclusions

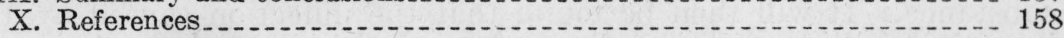

\section{INTRODUCTION}

Dicalcium silicate, $2 \mathrm{CaO} . \mathrm{SiO}_{2}$, is one of the major constituents of portland cement and is found also in blast furnace slags [1] ${ }^{1}$ and in certain refractories developed from lime and dolomite [2]. Knowledge of the properties of $2 \mathrm{CaO} . \mathrm{SiO}_{2}$ is therefore important to the users of these industrial products. It was the purpose of the present study to

\footnotetext{
1 Figures in brackets indicate literature references at the end of this paper.
} 
determine the behavior during heating and cooling of dicalcium silicate in binary mixtures with oxides, which either occur in ordinary industrial raw materials or have been added experimentally in the manufacture of portland cement. Such studies of simple systems are helpful in the investigation of polycomponent systems existing in industrial products.

Dicalcium silicate has three enantiotropic forms: alpha, beta, and gamma. The $\alpha \rightleftharpoons \beta$ inversion has been reported as occuring at $1,420^{\circ}$ $\mathrm{C}$ and the $\beta \rightleftharpoons \gamma$ at $675^{\circ} \mathrm{C}$ [3]. An increase in volume of about 10 percent accompanies the $\beta \rightleftharpoons \gamma$ inversion and causes the so-called "dusting" of dicalcium silicate and may result in a destructive expansion of materials in which it is an ingredient. Also, because gamma $2 \mathrm{CaO} . \mathrm{SiO}_{2}$ has no hydraulic properties, it is not desired in portland cement clinker. Consequently, preventing the transformation of the beta to the gamma form is of industrial importance. It has been found that a number of substances prevent this transformation by entering into solid solution with dicalcium silicate. Studies of the solubility of various substances in beta dicalcium silicate are therefore valuable because of their bearing on the beta to gamma inversion. This solubility may be determined in the following way.

If the addition of a substance to a compound having two enantiotropic forms causes the formation of a solid solution the temperature of the inversion will be altered providing the solute is more soluble in one of these forms than in the other. When saturation is reached, no further change in the inversion temperature will occur upon the addition of more of the solute if the observed change is due entirely to the formation of solid solution. In this way the measurement of the temperature of the $\alpha \rightleftharpoons \beta$ inversion of dicalcium silicate furnishes a means for estimating the limit of solubility of a substance in dicalcium silicate.

The addition of a substance to a compound such as dicalcium silicate may not only alter the temperature of the inversion but also cause the formation of new phases. The presence of an additional phase in a heat-treated preparation is evidence that the limit of solubility of the added substance in the compound has been exceeded at the temperature of heating. The presence of the new phase may be revealed by an inflection on the heating and cooling curves in addition to the inflection caused by the inversion.

If it is desired to know which of several inflections on a heating or cooling curve represents the inversion of the compound containing added material, it is usually necessary to examine a suitable series of such curves arranged in the order of increasing amounts of the added substance. It will then be found that the inflection caused by the inversion will become smaller, whereas the other inflections will become larger.

It is evident therefore that the temperature of the $\alpha \rightleftarrows \beta$ inversion of dicalcium silicate should be known accurately if one is to interpret properly the various inflections in heating and cooling curves. This is particularly important when the limit of solubility of a substance in dicalcium silicate is small and the temperature of the $\alpha \rightleftarrows \beta$ inversion is changed but slightly by the addition of the substance in question. 
As preliminary experiments with various samples of presumably pure dicalcium silicate prepared by the authors, and also by several other investigators at the National Bureau of Standards, gave inflections in heating and cooling curves that were usually higher than the reported temperature of the $\alpha \rightleftarrows \beta$ inversion of $1,420^{\circ} \mathrm{C}$ [3], it was decided to study the cause of this and to obtain more information on the $\alpha \rightleftarrows \beta$ inversion before attempting to investigate the limits of solubility of various substances in dicalcium silicate as determined by the effects on the temperature of the $\alpha \rightleftarrows \beta$ inversion.

Zerfoss and Davis [4] apparently were also confronted with the question of the temperature of the $\alpha \rightleftarrows \beta$ inversion of dicalcium silicate, for they state "Much difficulty was experienced in detecting the alpha-to-beta inversion of a pure preparation of $\mathrm{C}_{2} \mathrm{~S}$ in a mineralizerfree system. Despite numerous refinements in technique, one could not attach much certainty to the recorded inversion temperature; in fact only in the presence of a mineralizer $\left(\mathrm{CaF}_{2}\right)$ were the authors able to obtain a reliable heat effect."

The first part of the present paper deals with the application of heating and cooling curves to the determination of the temperature of the $\alpha \rightleftarrows \beta$ inversion of $2 \mathrm{CaO} . \mathrm{SiO}_{2}$ and of the effect of excess $\mathrm{CaO}$ or $\mathrm{SiO}_{2}$ (oxide constituents of $2 \mathrm{CaO} \cdot \mathrm{SiO}_{2}$ ) on the temperature of this inversion. The second part of the paper deals with the effects of additions of $\mathrm{Al}_{2} \mathrm{O}_{3}, \mathrm{MgO}, \mathrm{Fe}_{2} \mathrm{O}_{3}, \mathrm{CaF}_{2}, \mathrm{TiO}_{2}, \mathrm{BaO}, \mathrm{Cr}_{2} \mathrm{O}_{3}, \mathrm{Mn}_{2} \mathrm{O}_{3}$, $\mathrm{V}_{2} \mathrm{O}_{5}, \mathrm{P}_{2} \mathrm{O}_{5}, \mathrm{Na}_{2} \mathrm{O}$, and $\mathrm{K}_{2} \mathrm{O}$, on the temperature of the $\alpha \rightleftarrows \beta$ inversion, the extent to which they form solid solutions with the dicalcium silicate, and their effectiveness in preventing the $\beta$ to $\gamma$ inversion or dusting.

\section{MATERIALS AND GENERAL PROCEDURE FOR PRE- PARING AND TESTING MIXTURES}

All the materials were of analytical reagent quality. The source of $\mathrm{CaO}$ was precipitated "low alkali" $\mathrm{CaCO}_{3}$ which contained less than 0.042 percent of total determined impurities, including less than 0.010 percent of $\mathrm{K}$ and $\mathrm{Na}$ as sulfates and less than 0.010 percent of $\mathrm{MgO}$. Silica gel with a 0.06 percent residue nonvolatile with $\mathrm{HF}$ was the source of $\mathrm{SiO}_{2}$. The added substances were introduced as $\mathrm{Al}_{2} \mathrm{O}_{3} \cdot 3 \mathrm{H}_{2} \mathrm{O}, \mathrm{Mg}(\mathrm{OH})_{2}, \mathrm{Fe}_{2} \mathrm{O}_{3}, \mathrm{CaF}_{2}, \mathrm{TiO}_{2}, \mathrm{BaCO}_{3}, \mathrm{Cr}_{2} \mathrm{O}_{3}, 2 \mathrm{CaO} \cdot \mathrm{B}_{2} \mathrm{O}_{3}$, $\mathrm{Mn}_{2} \mathrm{O}_{3}, \mathrm{~V}_{2} \mathrm{O}_{5}, \mathrm{H}_{3} \mathrm{PO}_{4}, \mathrm{Na}_{2} \mathrm{CO}_{3}$, and $\mathrm{K}_{2} \mathrm{CO}_{3}$. Sufficient silica was added with the $2 \mathrm{CaO} \cdot \mathrm{B}_{2} \mathrm{O}_{3}$ to react with the $\mathrm{CaO}$ and form $2 \mathrm{CaO} \cdot \mathrm{SiO}_{2}$.

Mixtures of $\mathrm{CaCO}_{3}$ and silica gel proportioned in the molar ratio of $\mathrm{CaO}$ to $\mathrm{SiO}_{2}$ of 2.00 were prepared in 100 - to 200 -g quantities and tumbled for 8 to $12 \mathrm{hr}$ in 1-pt glass jars that contained a few wooden balls. One of these mixtures was heated for $1 \mathrm{hr}$ at $1,450^{\circ} \mathrm{C}$, cooled, and remixed by hand. This was repeated three times. The resulting material, largely $\gamma 2 \mathrm{CaO} . \mathrm{SiO}_{2}$ as shown by microscopical examination, was reserved as a "standard" sample of dicalcium silicate and was used throughout the investigation as one of the materials to calibrate and check the thermocouples by the temperature of its $\beta$ to $\alpha$ inversion as shown by heating curves.

Portions of about $5 \mathrm{~g}$ of the other mixtures of $\mathrm{CaCO}_{3}$ and silica gel were heated for $1 / 2 \mathrm{hr}$ at $1,440^{\circ}$ to $1,480^{\circ} \mathrm{C}$, cooled, and ground in an agate mortar. This was repeated three times. Each portion so pre- 
pared was then placed in the crucible of the apparatus used for obtaining differential heating and cooling curves and heated to about $1,470^{\circ} \mathrm{C}$ for $1 \mathrm{hr}$. The temperature of the $\alpha \rightleftharpoons \beta$ inversion was then determined. If the material did not give the desired temperature of inversion, the necessary adjustments were made on the batch material by adding very small quantities of $\mathrm{CaCO}_{3}$ or silica gel. The reasons for the necessity of this procedure will be discussed subsequently.

The standardized $\mathrm{CaCO}_{3}$-silica gel mixtures so prepared and tested were used in making the preparations of $2 \mathrm{CaO} . \mathrm{SiO}_{2}$ with added materials. About $5 \mathrm{~g}$ total weight of a standardized dicalcium silicate raw mix, plus the added material, were tumbled for 2 to $4 \mathrm{hr}$ in $2-\mathrm{oz}$ bottles that contained a single wooden ball. These preparations were heat-treated and remixed in the same manner as that used in testing the dicalcium silicate raw mix. Heating and cooling curves were then obtained with these mixtures.

Small samples of dicalcium silicate with each of the various additions were also quenched in mercury after heating them above the $\beta \rightarrow \alpha$ inversion temperature ${ }^{2}$ for one-half to one hour. These quenched samples were examined petrographically and X-ray patterns ${ }^{3}$ were obtained representative of those preparations in which the beta form of the dicalcium silicate was preserved.

\section{CHOICE OF THE METHOD OF DIFFERENTIAL HEATING CURVES}

Time-versus-temperature curves were used in many of the previous studies of phase equilibria in silicate systems, including determinations of melting points. Rankin and Wright [3] in 1915 reported their value of $1,420^{\circ} \mathrm{C}$ for the temperature of the $\alpha \rightleftharpoons \beta$ inversion of $2 \mathrm{CaO} . \mathrm{SiO}_{2}$ obtained from such curves.

More recently differential heating curves have gained favor. One of the present authors [5] showed that differential heating curves gave an accurate location of the temperature of the $\beta \rightarrow \alpha$ inversion of $\mathrm{CaSO}_{4}$. Such curves can be used also to determine melting points.

A time-temperature curve for the melting of $2 \mathrm{CaO} \cdot \mathrm{B}_{2} \mathrm{O}_{3}$ is shown in the right-hand portion of figure 1 and a time-temperature curve for the $\beta \rightarrow \alpha$ inversion of a sample of $2 \mathrm{CaO}^{-\mathrm{SiO}_{2}}$ in the left-hand portion of the same figure. For comparison, the corresponding differential heating curves are also shown. It is evident from an examination of the two sets of curves that the differential heating curves give a more definite location of the temperature of change-of-phase than do curves of time versus temperature. Hence the selection of differential heating curves in the present study.

\footnotetext{
3 In general discussions of the transformation between the alpha and beta forms the symbol $\alpha \rightleftarrows \beta$ is used 3. In general discussions of the transformation between the alpha and beta forms the symbol $\alpha \rightleftarrows \beta$ is used
to indicate the inversion without regard to the direction of change of temperature. When the temperature is raised, $i$. e., in heating curves, the direction of inversion is from $\beta$ to $\alpha$ and the symbol $\beta \rightarrow \alpha$ is adopted.
With falling temperature the inversion is in the reverse direction and the symbol $\alpha \rightarrow \beta$ is used.

${ }_{3}$ Prepared by E. Golovato and B. L. Steierman and interpreted by H. F. McMurdie.
} 


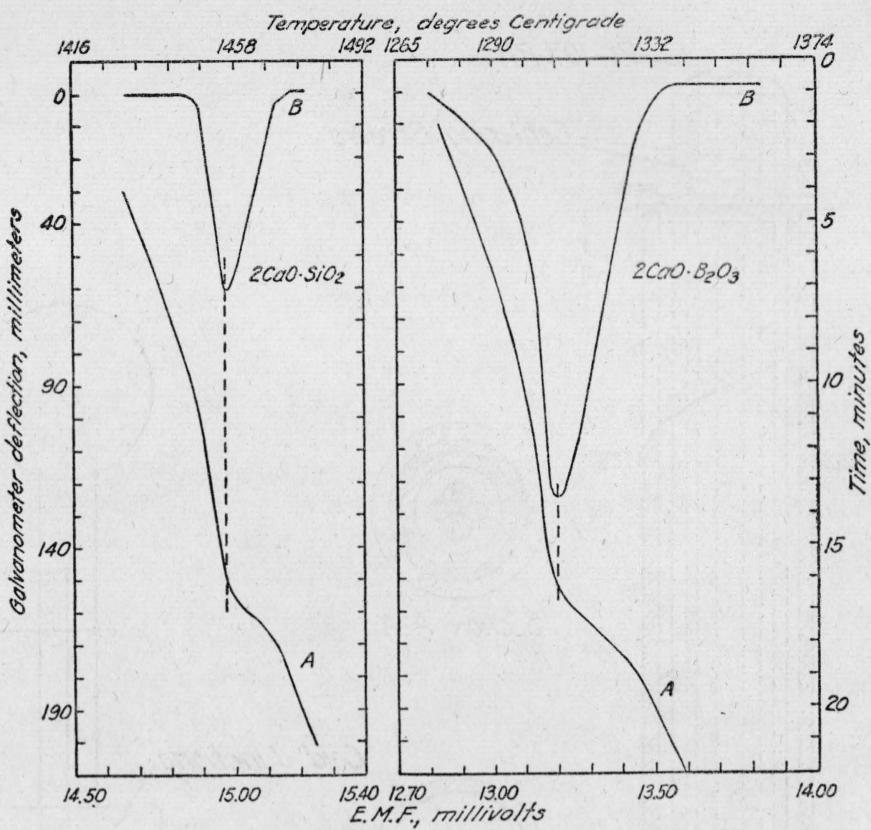

FIGURE 1.-Time-temperature and differential heating curves for the melting of $2 \mathrm{CaO} . \mathrm{B}_{2} \mathrm{O}_{3}$ and for the $\beta \rightarrow \alpha$ inversion of $2 \mathrm{CaO} . \mathrm{SiO}_{2}$.

The time-temperature curves, $A$, have been rotated $90^{\circ}$ ?clockwise for comparison with the differential heating curves, $B$. Dotted lines show the relation between curve $A$ and the maximum deflection of curve $B$. Time-temperature deflection data for both curves were obtained in a single heating of each material. Heating rate, approximately 3 degrees centigrade per minute.

\section{APPARATUS AND PROCEDURE FOR OBTAINING DIFFERENTIAL HEATING AND COOLING CURVES}

The arrangement of the crucibles and supports in the furnace used for obtaining differential heating and cooling curves is shown in detail in figure 2. The crucibles were a narrow, deep type, recommended by White [6] for the determination of melting points. They were 1 inch deep and semicircular in cross section, with a 0.25 -in. radius, and held 2 to $4 \mathrm{~g}$ of powdered material.

The differential thermocouple, $\mathrm{Pt}: \mathrm{Pt}-10$-percent $\mathrm{Rh}$, was made of wire calibrated in the Bureau's Pyrometry Section.

In obtaining the data for differential heating and cooling curves, the furnace temperature was changed at an approximately constant rate by suitable manipulation of the control [7] and of the rheostats regulating the heating current. Two rates were used, about 8.5 and 2.5 degrees centigrade/min. The faster rate was used in exploratory tests, and the slower rate in determining more exactly the temperature at which the heat effects occurred. At intervals of $1 \mathrm{~min}$ or less, if the deflection was changing rapidly, readings were taken of the emf of the thermocouple in contact with the sample in crucible 1 (fig. 2) and of the deflection of the galvanometer in series with thermocouple 1 and the opposed thermocouple in the reference material (corundum) in crucible 2. Seldom more than 1 second intervened between the final balancing of the potentiometer and the reading of the deflection. A $680952-46-3$ 


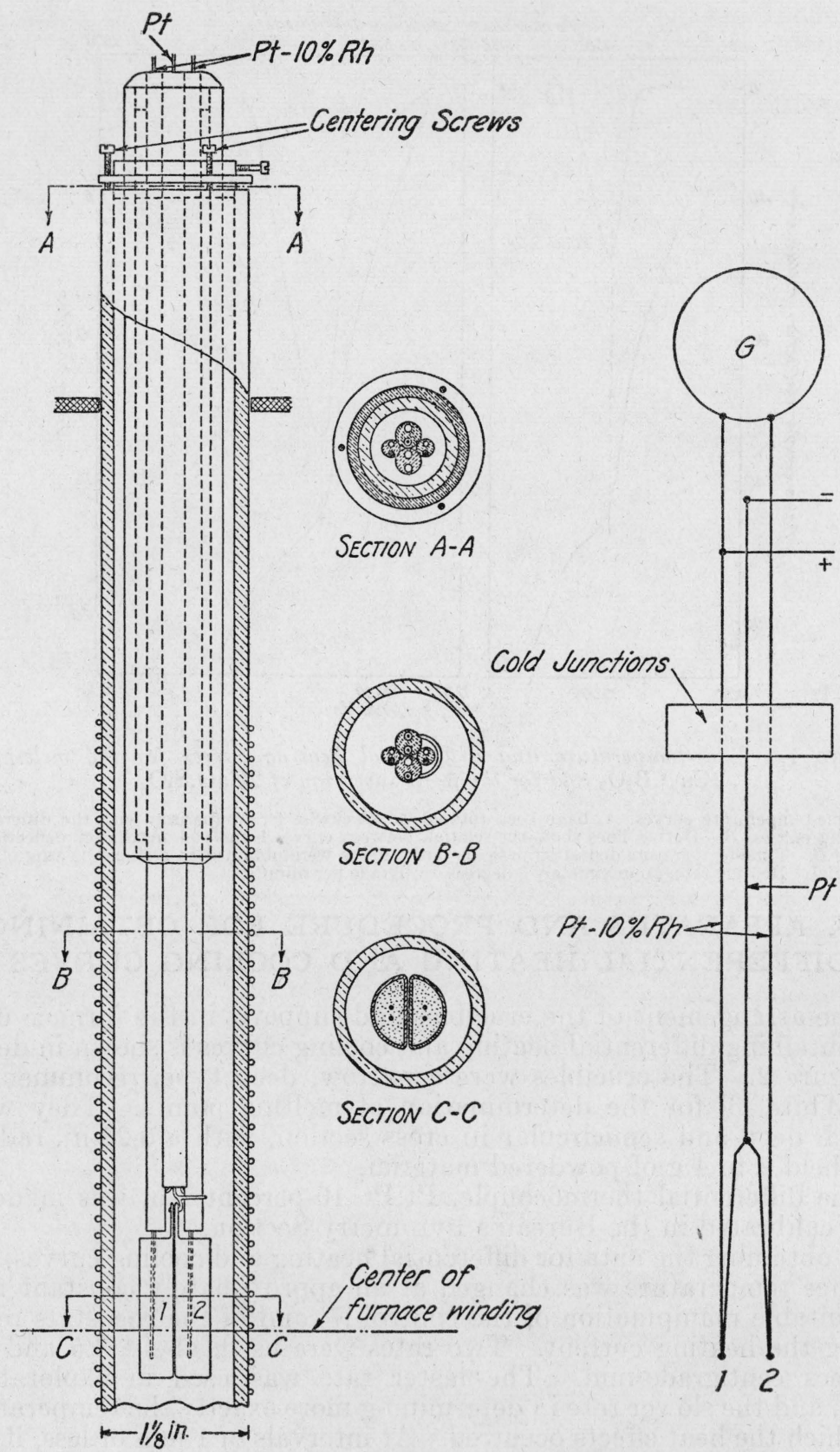

FIgURE 2.-Apparatus for obtaining differential heating and cooling curves. 
differential heating or cooling curve is based on a plot of these galvanometer deflections versus the emf of the thermocouple in the material under test.

The differential heating and cooling curves presented in figure 3 show the effects of the two rates of temperature change and the relam tive positions of curves obtained during heating and cooling of a particular preparation of dicalcium silicate. Tangents were drawn to facilitate selecting the temperature at which the maximum deflection of the galvanometer occurs when the material is heated. This pro-

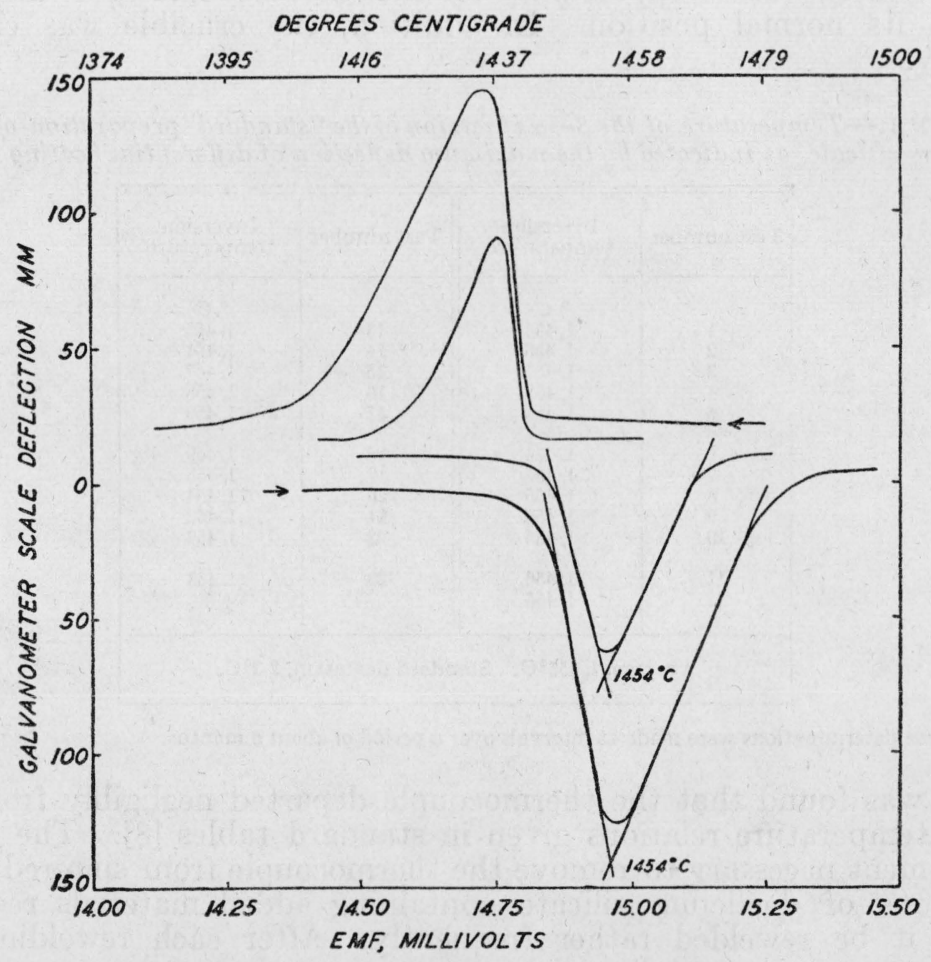

Figure 3.-Differential heating and cooling curves indicating temperature of the $\beta \rightleftarrows \alpha$ inversion of $2 \mathrm{CaO} . \mathrm{SiO}_{2}$.

Rates of temperature change, 8.5 and 2.5 degrees centigrade per minute. Curves showing the greater deflection were obtained at the faster rate. Arrows indicate the direction of change of temperature.

cedure of drawing tangents was found to be necessary when inflections on the curves were small and poorly defined. The temperature obtained during the heating cycle was always higher than that obtained during the cooling cycle of the same sample. This difference can be attributed to superheating or supercooling of the sample, but, because of the greater tendency toward supercooling, the temperatures obtained by heating were chosen as the more reliable.

The thermocouple was checked from time to time against the melting points of $\mathrm{K}_{2} \mathrm{SO}_{4}, 2 \mathrm{CaO} . \mathrm{B}_{2} \mathrm{O}_{3}, \mathrm{CaO} . \mathrm{MgO} .2 \mathrm{SiO}_{2}$, or $3 \mathrm{CaO} . \mathrm{B}_{2} \mathrm{O}_{3}$. Shifting of the thermocouple was prevented in some of the melting point determinations by means of a small platinum-wire guard clamped adjacent to the bead. 
The temperature of the $\beta$ to $\alpha$ inversion of the sample of $2 \mathrm{CaO} . \mathrm{SiO}_{2}$ reserved for calibration also served as a check on the thermocouple. Table 1 gives the values of 23 determinations of the $\beta$ to $\alpha$ inversion of this "standard" preparation of dicalcium silicate, as indicated by the maximum deflection of the differential heating curves. These determinations were made at intervals over a period of about 6 months. The average was $1,456^{\circ} \mathrm{C}$, with a standard deviation of $2.2^{\circ} \mathrm{C}$. The significance of this temperature will be discussed later. Dicalcium silicate was useful for the calibration because fusion did not occur, and hence there was no opportunity for the thermocouple to be displaced from its normal position. In addition, the crucible was cleaned easily.

TABLE 1.-Temperature of the $\beta \rightarrow \alpha$ inversion of the "standard"preparation of dicalcium silicate, as indicated by the maximum defleciion of differential heating curves *

\begin{tabular}{|c|c||c|c|}
\hline Test number & $\begin{array}{c}\text { Inversion } \\
\text { temperature }\end{array}$ & Test number & $\begin{array}{c}\text { Inversion } \\
\text { temperature }\end{array}$ \\
\cline { 2 - 4 } 1 & ${ }^{\circ}$ C & & $\circ C$ \\
2 & 1,458 & 13 & 1,455 \\
3 & 1,456 & 14 & 1,461 \\
4 & 1,457 & 15 & 1,457 \\
5 & 1,452 & 16 & 1,458 \\
6 & 1,453 & 17 & 1,459 \\
7 & 1,454 & 18 & 1,459 \\
8 & 1,457 & 19 & 1,455 \\
9 & 1,455 & 20 & 1,454 \\
10 & 1,456 & 22 & 1,452 \\
11 & 1,455 & 23 & 1,456 \\
12 & 1,456 & 1,455 & 1,453 \\
\hline \multicolumn{2}{c}{ Average, $1,456^{\circ} \mathrm{C}$. Standard deviation, $2.2^{\circ} \mathrm{C}}$. \\
\hline
\end{tabular}

- These determinations were made at intervals over a period of about 6 months.

It was found that the thermocouple departed negligibly from the emf temperature relations given in standard tables [8]. The rough treatment necessary to remove the thermocouple from sintered preparations of dicalcium silicate containing added materials required that it be rewelded rather frequently. After each rewelding the thermocouple was recalibrated.

\section{TEMPERATURE OF THE $\alpha \rightleftharpoons \beta$ INVERSION OF $2 \mathrm{CaO}^{\mathrm{S}} \mathrm{SiO}_{2}$}

As stated previously, it was found that various samples of dicalcium silicate which had been prepared by several investigators at this Bureau gave inflections in heating and cooling curves that were higher than the reported temperature of the $\alpha \rightleftharpoons \beta$ inversion of $1,420^{\circ} \mathrm{C}$ [3]. A total of eight batches of dicalcium silicate had been prepared and differential heating and cooling curves were obtained. Samples of all eight preparations were then carefully analyzed and the molar ratios of $\mathrm{CaO}$ to $\mathrm{SiO}_{2}$ computed. Table 2 gives these molar ratios together with the percentage of $\mathrm{R}_{2} \mathrm{O}_{3}$. It also contains the values of the $\beta \rightarrow \alpha$ and $\alpha \rightarrow \beta$ inversions ascertained from the respective heating and cooling curves (fig. 4) by the method of drawing tangents, as illustrated in figure 3. The rates of heating and cooling are also given in table 2 and figure 4. It can be seen from table 2 that for each prepara- 
tion the values of the $\beta \rightarrow \alpha$ inversion obtained by heating at different rates agreed very well. All of the values were above $1,420^{\circ} \mathrm{C}$. For the most part the temperatures of the $\alpha \rightarrow \beta$ inversions for each preparation also checked for the different cooling rates. However, as mentioned previously, the temperature of the $\beta \rightarrow \alpha$ inversions obtained with heating curves were invariably higher than the temperatures of the $\alpha \rightarrow \beta$ inversions obtained with cooling curves.

TABLE 2.-Temperatures of the $\beta \rightarrow \alpha$ inversion obtained by differential heating curves, and of the $\alpha \rightarrow \beta$ inversion by differential cooling curves, of eight preparations of chemically analyzed dicalcium silicate compositions

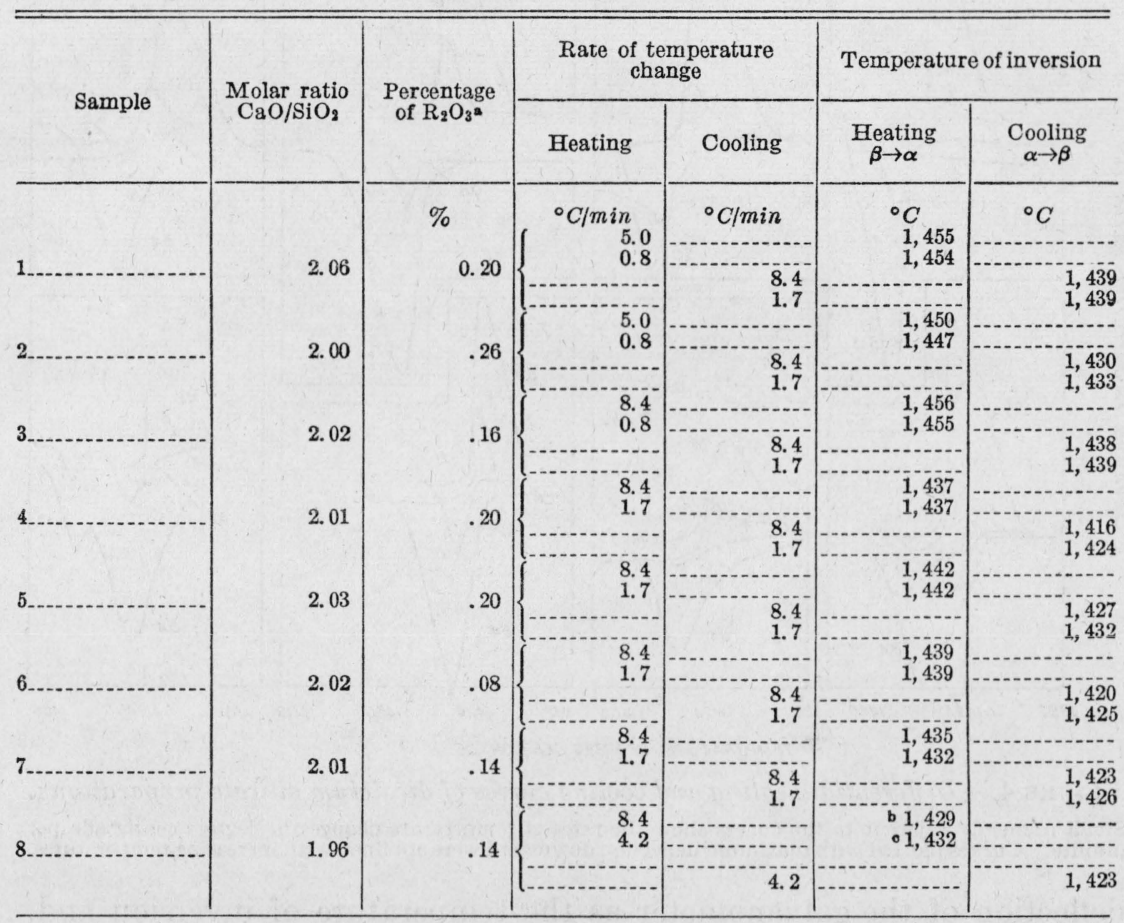

ancorrected for blank of approximately 0.1 percent of $\mathrm{R}_{2} \mathrm{O}_{3}$.

b Second heat effect at $1,454^{\circ} \mathrm{C}$.

- Second heat effect at $1,456^{\circ} \mathrm{C}$.

If, instead of selecting the temperatures at which the maximum galvanometer deflection occurs as representing the temperature of inversion, those temperatures at which the breaks in the heating and cooling curves first started from the normal had been selected, then temperatures other than those recorded in table 2 would have been chosen. This can be seen in figure 4. In several instances, notably for preparations $4,5,6$, and 8 , the breaks in the differential heating curves started below $1,420^{\circ} \mathrm{C}$. On the other hand, with these same preparations, the initial breaks in the cooling curves started considerably above $1,420^{\circ} \mathrm{C}$. In only one instance (preparation 1) were the temperatures of the initial breaks in both heating and cooling curves at approximately the same temperature. 
The selection of the temperature at which the breaks first start has, however, the disadvantages not only in that there is a spread in the temperature range between the initial breaks of the heating and cooling curves but also because these temperatures often occur at different temperatures at different heating and cooling rates and of the uncertainty of their location (fig. 4). Because of these difficulties it seemed advisable to choose the temperature of the maximum


TEMPERATURE, DEGREES CENTIGRADE.

FiguRE 4.-Differential heating and cooling curves of dicalcium silicate preparations. Small numerals adjacent to the curves show the rates of temperature changes in degrees centigrade per minute. Curves plotted with maximum deflection downward were obtained with increasing temperatures.

deflection of the galvanometer as the temperature of inversion and, as stated previously, to select the temperature of the $\beta \rightarrow \alpha$ inversion rather than the $\alpha \rightarrow \beta$ temperature of inversion because of the greater tendency toward supercooling than superheating. In addition, it should be recalled that the temperatures obtained by this method checked well at different heating rates (table 2).

In order to study the reason for the range in the observed $\alpha \rightleftarrows \beta$ inversion temperatures, both heating and cooling curves were obtained for a series of samples in which the $\mathrm{CaO} / \mathrm{SiO}_{2}$ molar ratio was varied slightly by adding $\mathrm{CaO}$ and $\mathrm{SiO}_{2}$ separately to portions of a single batch of dicalcium silicate base mix.

The temperature of the $\beta \rightarrow \alpha$ inversion of this base mix, as indicated by the maximum deflection of the galvanometer, was $1,458^{\circ} \mathrm{C}$, a value very close to $1,456^{\circ} \mathrm{C}$, the average inversion temperature of 
the "standard" sample reserved for calibration (table 1). The addition of 0.50 and 4.00 percent of $\mathrm{CaO}$ (table 3 ) did not change the $\beta \rightarrow \alpha$ inversion of the base mix. Likewise, these additions of $\mathrm{CaO}$ did not alter the $\alpha \rightarrow \beta$ inversion temperature. The addition of 0.12 percent of $\mathrm{SiO}_{2}$ did not lower the $\beta \rightarrow \alpha$ inversion temperature from $1,458^{\circ} \mathrm{C}$, but when the percentage was increased to 0.19 , this inversion was lowered to $1,438^{\circ} \mathrm{C}$. The further additions of $\mathrm{SiO}_{2}$ (table 3) caused no further significant alteration of the temperature of the $\beta \rightarrow \alpha$ inversion. However, the addition of 1.00 percent or more of $\mathrm{SiO}_{2}$ resulted in the appearance of a second inflection in the heating

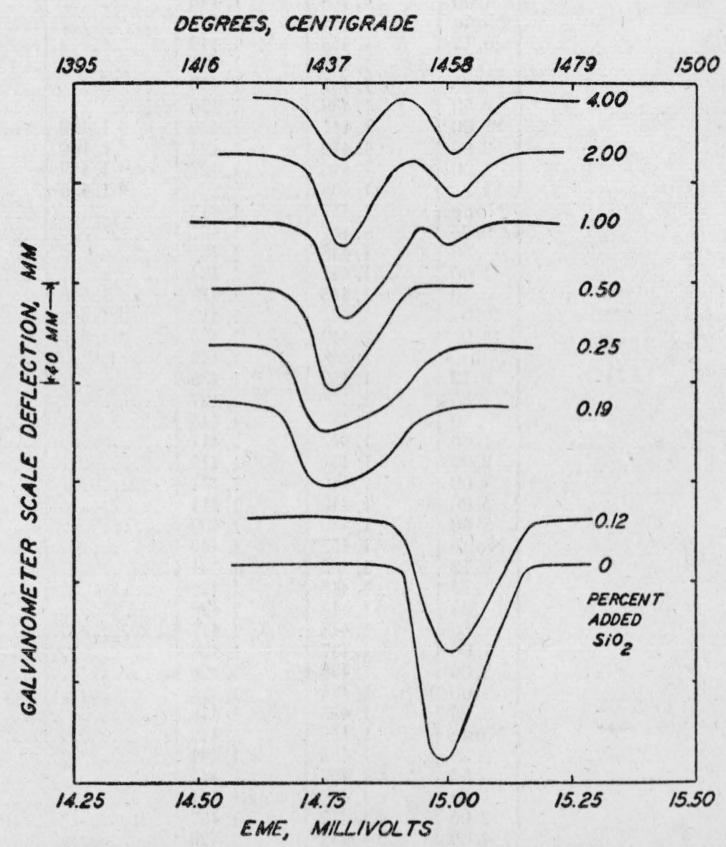

Figure 5.-Differential heating curves.

Effect of added $\mathrm{SiO}_{2}$ on the heating curve of $2 \mathrm{CaO}_{2} \mathrm{SiO}_{2}$. The deflection at about $1,460^{\circ}$ obtained with mixtures containing 1.00 percent or more added $\mathrm{SiO}_{2}$ is assumed to represent melting of the $3 \mathrm{CaO}_{2} 2 \mathrm{SiO}_{2}-$ $\mathrm{CaO} . \mathrm{SiO}_{2}$ eutectic. Heating rate 2.5 degrees centigrade per minute.

curves (fig. 5) somewhat similar to those obtained with preparation number 8 shown in figure 4 where the molar ratio of $\mathrm{CaO}$ to $\mathrm{SiO}_{2}$ was 1.96 to 1 . The relative sizes of the two inflections in the three upper heating curves of figure 5 demonstrate that these second heat effects do not represent the $\beta \rightarrow \alpha$ inversion temperature even though they occur at approximately $1,458^{\circ} \mathrm{C}$. Presumably the additional heat effects were caused by the melting of the eutectic between $3 \mathrm{CaO} .2 \mathrm{SiO}_{2}$ and $\mathrm{CaO}_{3} \mathrm{SiO}_{2}$ [3]. These second inflections did not appear on the cooling curves because the temperatures of the inflections were lowered by undercooling to coincide with that of the $\alpha \rightarrow \beta$ inversion temperature of the dicalcium silicate. 
TABLE 3.- Results of differential heating and cooling curves of $2 \mathrm{CaO}^{-\mathrm{SiO}_{2}}$ containing various added materials *

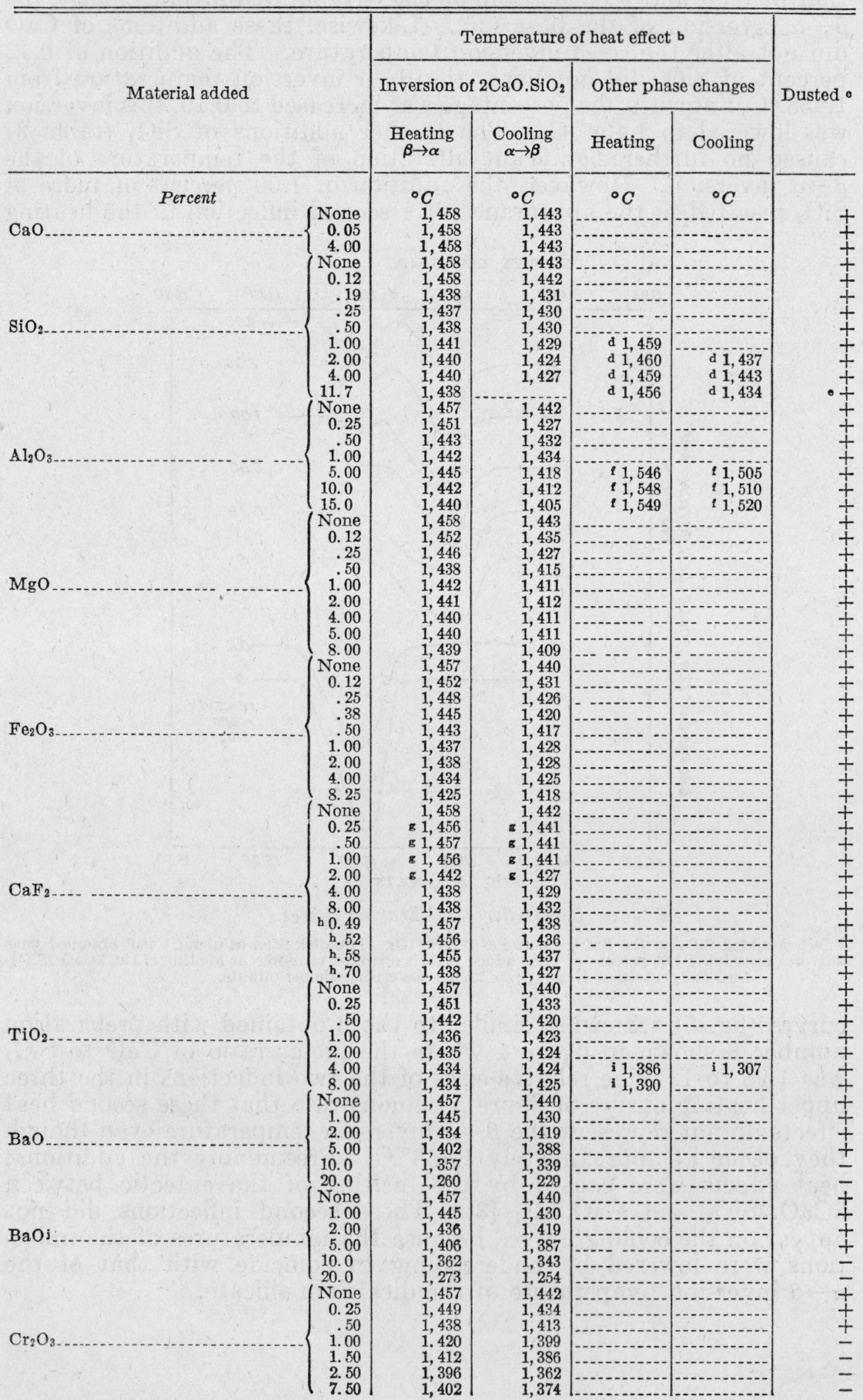

See footnotes at end of table. 
TABLE 3.- Results of differential heating and cooling curves of $2 \mathrm{CaO}^{-\mathrm{SiO}_{2}}$ containing various added materials a - Continued

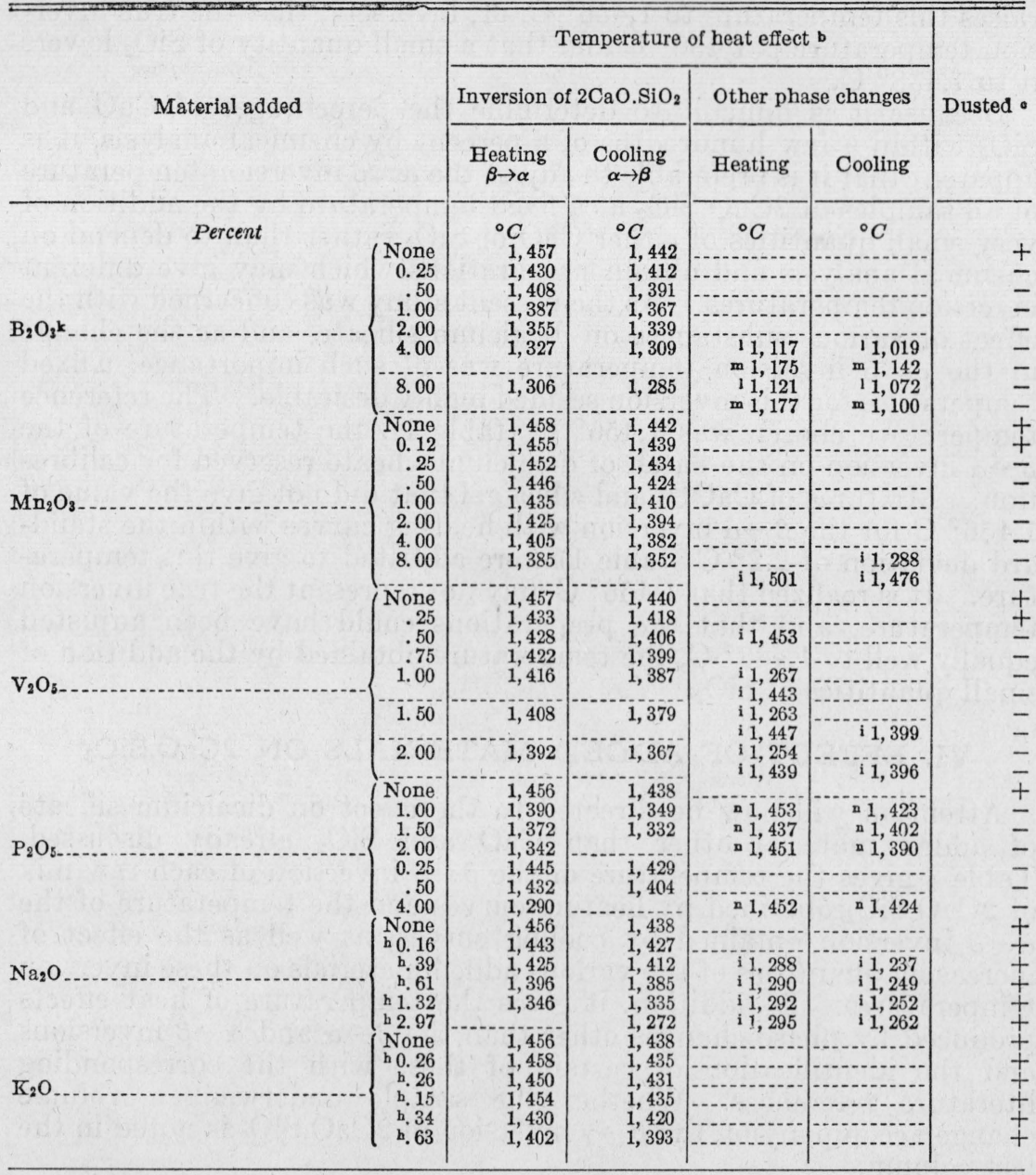

a The rate of temperature change was constant, usually about 2.5 degrees centigrade per min. The materials were added to portions of mixtures, prepared in 100- to 200-g quantities, of CaCO 3 and silica gel with a molar ratio $\mathrm{CaO} / \mathrm{SiO}_{2}$ of 2.00 . Preparations were heated for $1 / 2 \mathrm{hr}$ at $1,440^{\circ}$ to $1,480^{\circ} \mathrm{C}$, cooled, and ground. This was repeated 3 times. The samples were placed in the apparatus and held for 1 hr at $1,460^{\circ}$ to $1,480^{\circ}$ $\mathrm{C}$ before obtaining the heating and cooling curves.

b Temperatures were given by the intersection of tangents drawn to the inflections on the differential heating and cooling curves.

- A plus sign in the "Dusted" column indicates that the sample underwent the volume change accompanying the $\beta \longrightarrow \gamma$ inversion of $2 \mathrm{CaO}^{\mathrm{S}} \mathrm{SiO}_{2}$.

d Melting or freezing of the eutectic $3 \mathrm{CaO} \cdot 2 \mathrm{SiO}_{2}-\mathrm{CaO} \cdot \mathrm{SiO}_{2}$. G. A. Rankin and F. E. Wright, Am. J. Sci. [4], 29, 1 (1915).

- Incomplete dusting.

f Melting or freezing of the eutectic $2 \mathrm{CaO} \cdot \mathrm{SiO}_{2}-2 \mathrm{CaO} \cdot \mathrm{SiO}_{2} \cdot \mathrm{Al}_{2} \mathrm{O}_{3}$. See reference in footnote d.

$\mathrm{g}$ Inversion temperatures disregarded because of volatility of some of the fluorine in the added $\mathrm{CaF}_{2}$.

b Calculated from analysis made after the experiment. Analyses by R. B. Peppler.

i Unidentified.

3 Added in combination with silica gel in molar ratio $2 \mathrm{BaO} \mathrm{SiO}_{2}$.

Added as $2 \mathrm{CaO} . \mathrm{B}_{2} \mathrm{O}_{3}$ with silica gel in molar ratio $2 \mathrm{CaO}_{2} \cdot \mathrm{B}_{2} \mathrm{O}_{3}: \mathrm{SiO}_{2}$.

1 Melting or freezing of the eutectic $2 \mathrm{CaO} \cdot \mathrm{SiO}_{2}-\mathrm{CaO}_{2} \mathrm{SiO}_{2}-2 \mathrm{CaO}_{2} \mathrm{~B}_{2} \mathrm{O}_{3}$. E. P. Flint and L. S. Wells, J. Research NBS. 17, 727 (1936) RP941.

$\mathrm{m}$ Boundary $2 \mathrm{CaO} . \mathrm{SiO}_{2}-\mathrm{CaO} . \mathrm{SiO}_{2}$. See reference in footnote 1 .

n Invariant point $2 \mathrm{CaO} \cdot \mathrm{SiO}_{2}-3 \mathrm{CaO} .2 \mathrm{SiO}_{2}-7 \mathrm{CaO} \cdot 2 \mathrm{SiO}_{2} \cdot \mathrm{P}_{2} \mathrm{O}_{5}$. R. L. Barrett, and W. J. McCaughey Am. Mineral. 27, 680 (1942). 
To summarize, one may assume that the inversion temperature of pure dicalcium silicate is $1,438^{\circ} \mathrm{C}$ and that a small quantity of $\mathrm{CaO}$ raises this temperature to $1,456^{\circ} \mathrm{C}$, or, inversely, that the true inversion temperature is $1,456^{\circ} \mathrm{C}$ and that a small quantity of $\mathrm{SiO}_{2}$ lowers it to $1,438^{\circ} \mathrm{C}$.

Because it is difficult to determine the percentages of $\mathrm{CaO}$ and $\mathrm{SiO}_{2}$ within a few hundredths of a percent by chemical analysis, it is apparent that it is preferable to adjust the $\alpha \rightleftharpoons \beta$ inversion temperature of all samples of $2 \mathrm{CaO} . \mathrm{SiO}_{2}$ at a fixed temperature by the addition of very small quantities of either $\mathrm{CaO}$ or $\mathrm{SiO}_{2}$ rather than to depend on chemical analysis and obtain preparations which may give different inversion temperatures. As the present study was concerned with the effect of various substances on dicalcium silicate, and as the change in the $\alpha \rightleftharpoons \beta$ inversion temperature was of such importance, a fixed temperature for this inversion seemed highly desirable. The reference temperature chosen was $1,456^{\circ} \mathrm{C}$ (table 1 ), the temperature of the $\beta \rightarrow \alpha$ inversion on the batch of dicalcium silicate reserved for calibration. Mixtures of $\mathrm{CaCO}_{3}$ and silica gel that did not give the value of $1,456^{\circ} \mathrm{C}$ for the $\beta \rightarrow \alpha$ inversion with heating curves within the standard deviation of $2.2^{\circ} \mathrm{C}$ (table 1) were adjusted to give this temperature. It is realized that $1,456^{\circ} \mathrm{C}$ may not represent the true inversion temperature, and that the preparations could have been adjusted equally well to $1,438^{\circ} \mathrm{C}$, the temperature obtained by the addition of small quantities of $\mathrm{SiO}_{2}$.

\section{EFFECT OF ADDED MATERIALS ON $2 \mathrm{CaO} \cdot \mathrm{SiO}_{2}$}

Attention will now be directed to the effect on dicalcium silicate of added material other than $\mathrm{CaO}$ and $\mathrm{SiO}_{2}$ already discussed. Table 3 gives the temperature of the $\beta \rightarrow \alpha$ inversion of each raw mix of $2 \mathrm{CaO} . \mathrm{SiO}_{2}$ obtained by heating curves and the temperature of the $\alpha \rightarrow \beta$ inversion obtained by cooling curves, as well as the effect of increasing quantities of the various added materials on these inversion temperatures. In addition, it gives the temperature of heat effects produced by phase changes other than the $\beta \rightarrow \alpha$ and $\alpha \rightarrow \beta$ inversions and the identification of certain of these with the corresponding literature references. Whether the sample underwent a volume change accompanying the $\beta \rightarrow \gamma$ inversion of $2 \mathrm{CaO} . \mathrm{SiO}_{2}$ is noted in the last column.

When phase changes in addition to the $\alpha \rightleftharpoons \beta$ inversion occurred with the dicalcium silicate containing added materials $\left(\mathrm{Al}_{2} \mathrm{O}_{3}, \mathrm{TiO}_{2}, \mathrm{~B}_{2} \mathrm{O}_{3}\right.$, $\mathrm{Mn}_{2} \mathrm{O}_{3}, \mathrm{~V}_{2} \mathrm{O}_{5}, \mathrm{P}_{2} \mathrm{O}_{5}$, and $\mathrm{Na}_{2} \mathrm{O}$ ), the shapes of the heating curves were typical of those obtained with increasing amounts of $\mathrm{SiO}_{2}$ (fig. 5). Where additional phase changes did not occur $\left(\mathrm{MgO}, \mathrm{Fe}_{2} \mathrm{O}_{3}, \mathrm{CaF}_{2}\right.$, $\mathrm{BaO}, \mathrm{Cr}_{2} \mathrm{O}_{3}$, and $\mathrm{K}_{2} \mathrm{O}$ ) the shapes of the curves more closely resembled those for the addition of $\mathrm{BaO}$ shown in figure 6 . The effects of the various additions are summarized graphically in figures $7,8,9,10$, and 11 .

\section{1. $\mathrm{Al}_{2} \mathrm{O}_{3}, \mathrm{MgO}, \mathrm{Fe}_{2} \mathrm{O}_{3}, \mathrm{TiO}_{2}, \mathrm{AND} \mathrm{CaF}$}

It can be seen from the data of table 3 and the plot of figure 7 that $\mathrm{Al}_{2} \mathrm{O}_{3}, \mathrm{MgO}, \mathrm{Fe}_{2} \mathrm{O}_{3}$, TiO $\mathrm{TiO}_{2}$, and $\mathrm{CaF}_{2}$ resembled each other in their effects on the $\beta \rightarrow \alpha$ inversion in that a rather small quantity of any 


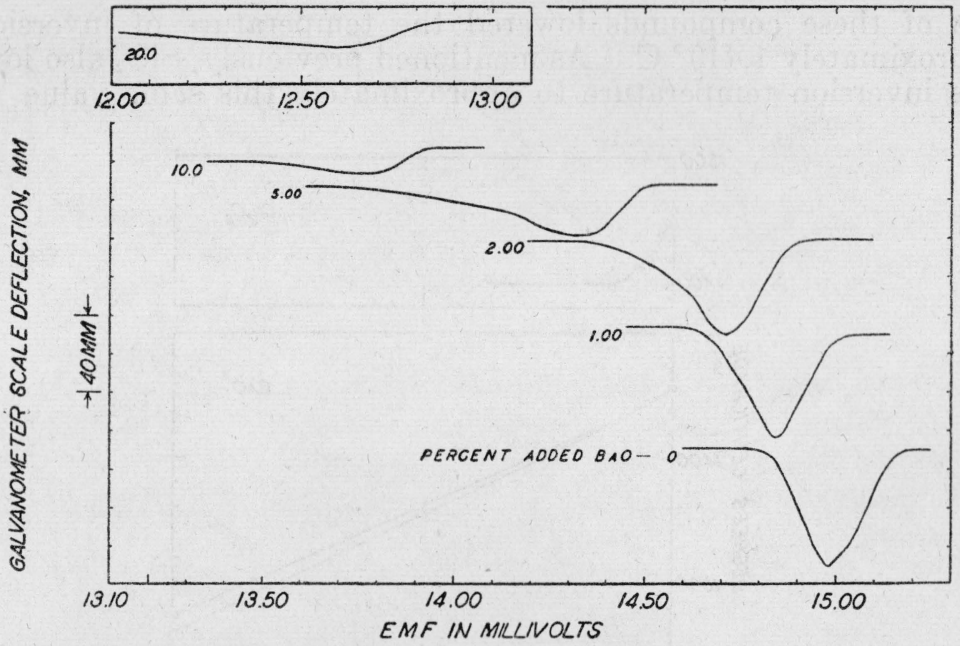

Figure 6.-Differential heating curves.

Effect of added $\mathrm{BaO}$ on the heating curve of $2 \mathrm{CaO} . \mathrm{SiO}_{2}$. Heating rate 2.5 degrees centigrade per minute.

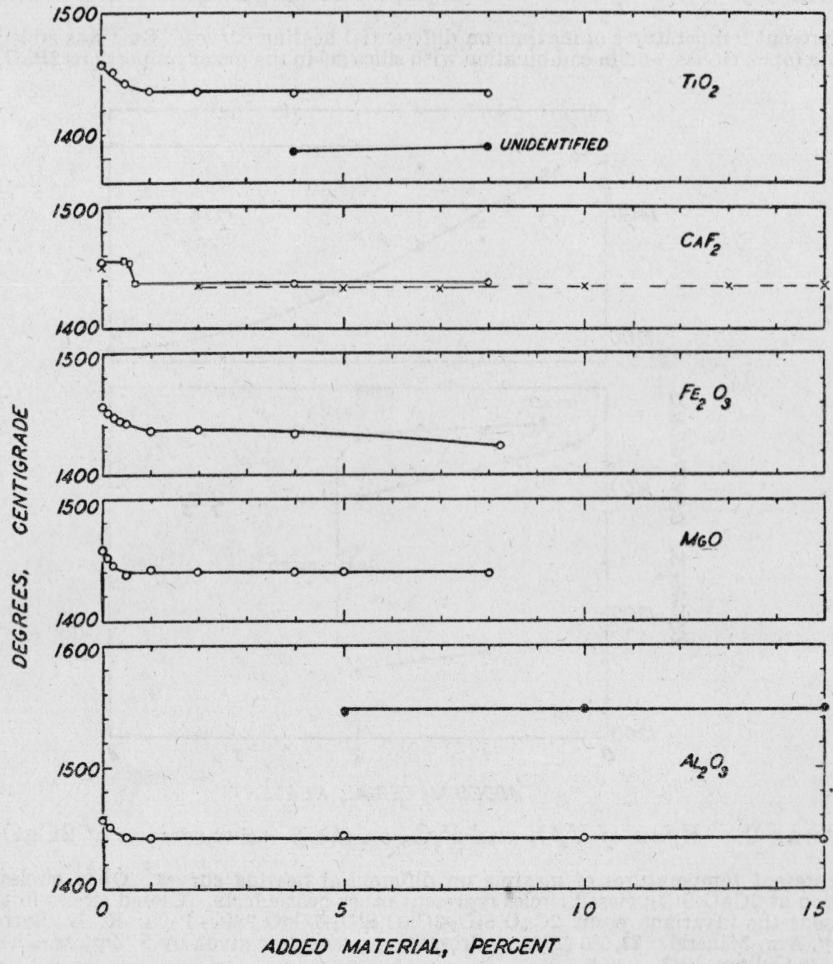

Figure 7.-Effect of $\mathrm{Al}_{2} \mathrm{O}_{3}, \mathrm{MgO}, \mathrm{Fe}_{2} \mathrm{O}_{3}, \mathrm{CaF}_{2}$, and $\mathrm{TiO}_{2}$ on the $\beta \rightarrow \alpha$ inversion of $2 \mathrm{CaO} . \mathrm{SiO}_{2}$

Points represent temperatures of maxima on differential heating curves. Open circles and squares represent the inversion of $2 \mathrm{CrO}_{8} . \mathrm{SiO}_{2}$. Closed circles represent other heat effects, unidentified for $\mathrm{TiO}_{2}$ and assumed to be the melting of the eutectic $2 \mathrm{CaO}$. SiO $-2 \mathrm{CaO} \cdot \mathrm{Al}_{2} \mathrm{O}_{3} \cdot \mathrm{SiO}_{2}$ in the diagram for $\mathrm{Al}_{2} \mathrm{O}_{3}$. In the diagram for $\mathrm{CaF}_{2}$, squares represent analyzed semples and crosses represent data given by $\mathrm{S}$. Zerfoss. Thesis, The Pennsylvania State College, 1942. 
one of these compounds lowered the temperature of inversion to approximately $1,440^{\circ} \mathrm{C}$. As mentioned previously, $\mathrm{SiO}_{2}$ also lowered this inversion temperature to approximately this same value. The
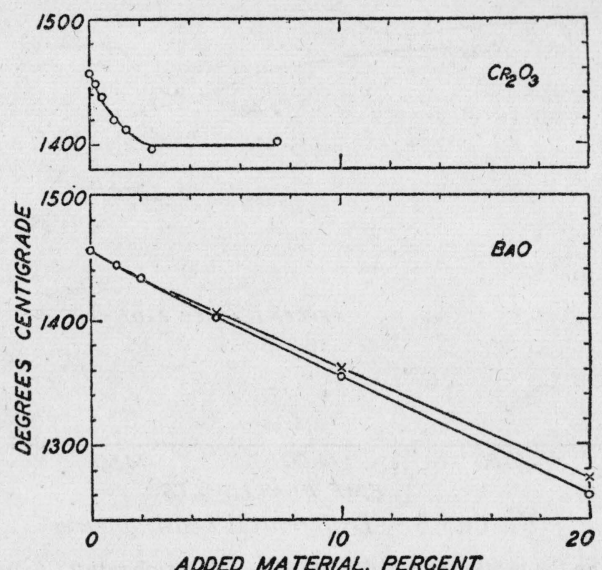

Figure 8.-Effect of $\mathrm{BaO}$ and $\mathrm{Cr}_{2} \mathrm{O}_{3}$ on the $\beta \rightarrow \alpha$ inversion of $2 \mathrm{CaO} . \mathrm{SiO}_{2}$.

Points represent temperatures of maxima on differential heating curves. $\mathrm{BaO}$ was added both alone as the carbonate (open circles) and in combination with silica gel in the molar proportions $2 \mathrm{BaO}^{-\mathrm{SiO}_{2}}$ (crosses).



Figure 9.-Efject of $\mathrm{V}_{2} \mathrm{O}_{5}$ and $\mathrm{P}_{2} \mathrm{O}_{5}$ on the $\beta \rightarrow \alpha$ inversion of $2 \mathrm{CaO} \mathrm{SiO}_{2}$.

Points represent temperatures of maxima on differential heating curves. Open circles represent the $\beta \rightarrow \alpha$ inversion at $2 \mathrm{CaO}$. SiO 2 ; closed circles represent other heat effects. Closed circles in the diagram for $\mathrm{P}_{2} \mathrm{O}$. represent the invariant point $2 \mathrm{CaO} . \mathrm{SiO}_{2}-3 \mathrm{CaO} \cdot \mathrm{SiO}_{2}-7 \mathrm{CaO}_{2} 2 \mathrm{SiO}_{2} \cdot \mathrm{P}_{2} \mathrm{O}_{3}$. R. L. Barrett and W. J. McCaughey, Am. Mineral. 27,680 (1942). Crosses represent data given by S. Zerfoss. Thesis, The Pennsylvania State College, 1942.

additions of larger amounts of $\mathrm{TiO}_{2}$ or of $\mathrm{Al}_{2} \mathrm{O}_{3}$ caused the appearance of heat effects in addition to that caused by the $\alpha \rightleftarrows \beta$ inversion, and in this respect resembled the behavior of $\mathrm{SiO}_{2}$. Additional heat 
effects were not observed between $1,250^{\circ}$ and $1,540^{\circ} \mathrm{C}$ for dicalcium silicate with the other added materials of this group. Under the conditions prevailing in these experiments, none of these compounds prevented the $\beta \rightarrow \gamma$ inversion of $2 \mathrm{CaO} . \mathrm{SiO}_{2}$, or dusting.

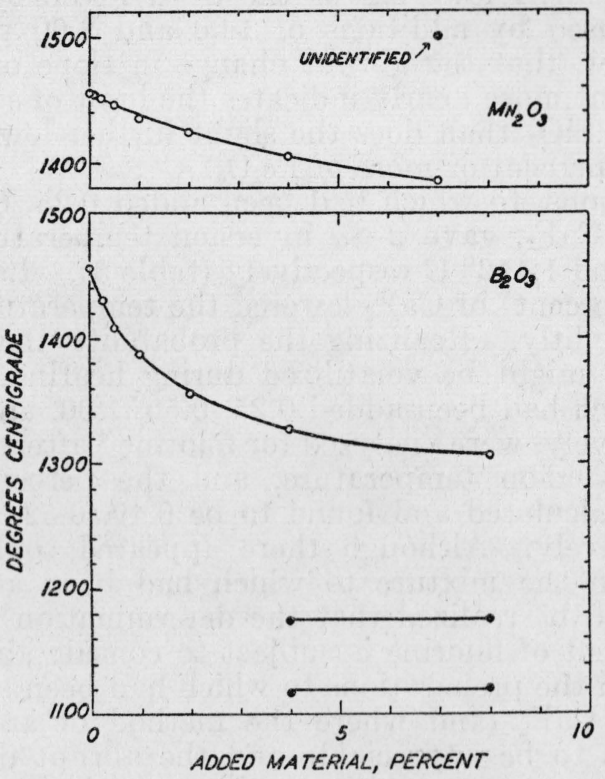

Figure 10.-Effect of $\mathrm{B}_{2} \mathrm{O}_{3}$ and $\mathrm{Mn}_{2} \mathrm{O}_{3}$ on the $\beta \rightarrow \alpha$ inversion of $2 \mathrm{CaO} . \mathrm{SiO}_{2}$.

Points represent temperatures of maxima on differential heating curves. Open circies represent the $\beta \rightarrow \alpha$ inversion of $2 \mathrm{CaO}_{\text {. }} \mathrm{SiO}_{2}$; closed circles represent other heat effects, unidentified in the case of $\mathrm{Mn}_{2} \mathrm{O}_{3}$. In the diagram for $\mathrm{B}_{2} \mathrm{O}_{3}$ these heat effects are assumed to represent the melting of the ternary eutectic $2 \mathrm{CaO} . \mathrm{SiO}_{2}-\mathrm{CaO} . \mathrm{SiO}_{2}-2 \mathrm{CaO} . \mathrm{B}_{2} \mathrm{O}_{3}$ at $1,118^{\circ} \mathrm{C}$, and the disappearance of the phase $\mathrm{CaO} . \mathrm{SiO}_{2}$ at $1,176^{\circ} \mathrm{C}$.

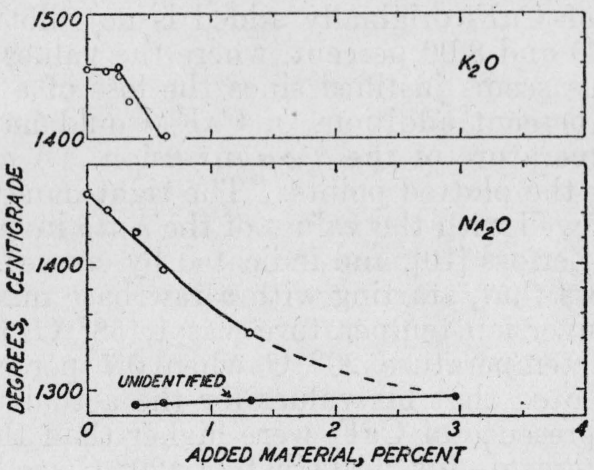

Figure 11.-Effect of $\mathrm{Na}_{2} \mathrm{O}$ and $\mathrm{K}_{2} \mathrm{O}$ on the $\beta \rightarrow \alpha$ inversion of $2 \mathrm{CaO} \cdot \mathrm{SiO}_{2}$.

Points represent temperatures of maxima on the differential heating curves. Open circles represent the $\beta \rightarrow \alpha$ inversion of $2 \mathrm{CaO} . \mathrm{SiO}_{2}$, closed circles represent an unidentified heat effect. The compositions of these samples were determined by analysis after the heating curves were obtained.

Burdick [9], using heating curves, reported a maximum solubility of about 0.5 percent of $\mathrm{Fe}_{2} \mathrm{O}_{3}$ in dicalcium silicate and a lowering of the $\beta \rightarrow \alpha$ inversion temperature to $1,361^{\circ} \mathrm{C}$. He also reported a ternary eutectic $\left(2 \mathrm{CaO} . \mathrm{SiO}_{2}-3 \mathrm{CaO} . \mathrm{SiO}_{2}-2 \mathrm{CaO} . \mathrm{Fe}_{2} \mathrm{O}_{3}\right)$ melting at 
$1,414^{\circ} \mathrm{C}$, and a eutectic between $2 \mathrm{CaO} \cdot \mathrm{SiO}_{2}$ and $2 \mathrm{CaO} \cdot \mathrm{Fe}_{2} \mathrm{O}_{3}$ melting at $1,428^{\circ} \mathrm{C}$. Heat effects corresponding to these phenomena were not observed in the present work.

It can be seen in figure 7 that additions of 4.00 and 8.25 percent of $\mathrm{Fe}_{2} \mathrm{O}_{3}$ caused a slight lowering of the $\beta \rightarrow \alpha$ inversion temperature beyond that caused by additions of 1.00 and 2.00 percent. It is believed, however, that the abrupt change in slope of the curve at about 1.00 percent more nearly indicates the limit of solid solution of $\mathrm{Fe}_{2} \mathrm{O}_{3}$ in $\alpha-2 \mathrm{CaO} . \mathrm{SiO}_{2}$ than does the slight further lowering with the addition of 4.00 percent or more of $\mathrm{Fe}_{2} \mathrm{O}_{3}$.

Four preparations, to which had been added $0.25,0.50,1.00$, and 2.00 percent of $\mathrm{CaF}_{2}$, gave $\beta \rightarrow \alpha$ inversion temperatures of $1,456^{\circ}$, $1,457^{\circ}, 1,456^{\circ}$, and $1,442^{\circ} \mathrm{C}$ respectively (table 3 ). Larger additions (4.00 and 8.00 percent) of $\mathrm{CaF}_{2}$ lowered the temperature of the $\beta \rightarrow \alpha$ inversion but slightly. Realizing the probability that some of the fluorine of $\mathrm{CaF}_{2}$ might be volatilized during heating, the first four mixtures, to which had been added $0.25,0.50,1.00$, and 2.00 percent of $\mathrm{CaF}_{2}$, respectively, were analyzed for fluorine ${ }^{4}$ after the determinations of the inversion temperature, and the percentage of $\mathrm{CaF}_{2}$ remaining was calculated and found to be $0.49,0.52,0.58$, and 0.70 percent, respectively. Although there appeared to be more $\mathrm{CaF}_{2}$ (0.49 percent) in the mixture to which had been added but 0.25 percent, it should be realized that the determination of only 1 or 2 tenths of a percent of fluorine is subject to considerable error. The loss of fluorine in the preparations to which had been added 1.00 and 2.00 percent of $\mathrm{CaF}_{2}$ (and where the method of analysis is more reliable) appears to be appreciable and the abrupt decrease in the $\beta \rightarrow \alpha$ inversion temperature consequently appears to be between 0.58 and 0.70 percent of $\mathrm{CaF}_{2}$ (see table 3 and fig. 7 ) rather than between 1.00 and 2.00 percent. Hence, it is concluded that the limit of solubility of $\mathrm{CaF}_{2}$ in $2 \mathrm{CaO} . \mathrm{SiO}_{2}$ is about 0.7 percent. This abrupt change in $\beta \rightarrow \alpha$ inversion temperature is represented in figure 7 by squares. The percentage of $\mathrm{CaF}_{2}$ originally added is not plotted in figure 7 except for the 4.00 and 8.00 percent, where the values are plotted as open circles. This seems justified since the loss of a portion of the 4 percent and 8 percent additions of $\mathrm{CaF}_{2}$ would have little or no effect on the temperature of the $\beta \rightarrow \alpha$ inversion. A curve was then drawn connecting the plotted points. The right-hand portion of the curve agrees very well with the values of the $\alpha \rightleftarrows \beta$ inversion temperature obtained by Zerfoss [10], and indicated by crosses. The present investigation shows that, starting with a raw base mix of $2 \mathrm{CaO} . \mathrm{SiO}_{2}$ where the $\beta \rightarrow \alpha$ inversion temperature was $1,458^{\circ} \mathrm{C}$, the addition of $\mathrm{CaF}_{2}$ lowers this temperature $20^{\circ} \mathrm{C}$ when 0.7 percent or more is added. Zerfoss noted that his values for the actual temperature of inversion in the presence of $\mathrm{CaF}_{2}$ were higher than the temperature reported in the literature for $2 \mathrm{CaO} \cdot \mathrm{SiO}_{2}\left(1,420^{\circ} \mathrm{C}\right.$ see [3]). Whether one concludes that the temperature of inversion is raised or lowered by addition of $\mathrm{CaF}_{2}$ depends, therefore, on what temperature is accepted as that representing the $\alpha \rightleftarrows \beta$ inversion of $2 \mathrm{CaO} . \mathrm{SiO}_{2}$, and shows the importance of fixing this temperature.

The data shown in figure 7 and in table 3 indicate maximum solubility limits for $\mathrm{Al}_{2} \mathrm{O}_{3}, \mathrm{MgO}, \mathrm{Fe}_{2} \mathrm{O}_{3}, \mathrm{CaF}_{2}$, and $\mathrm{TiO}_{2}$ in $\alpha-2 \mathrm{CaO} . \mathrm{SiO}_{2}$ of approximately $0.5,0.5,1.0,0.7$, and 1.0 percent, respectively.

\footnotetext{
- The preparations were analyzed by R. B. Peppler.
} 


\section{2. $2 \mathrm{BaO} . \mathrm{SiO}_{2}$ AND $\mathrm{BaO}$}

The effect of both barium orthosilicate, $2 \mathrm{BaO} \mathrm{SiO}_{2}$ and of $\mathrm{BaO}$, on the $\beta \rightarrow \alpha$ inversion of $2 \mathrm{CaO} . \mathrm{SiO}_{2}$ was investigated. For studying the effect of $2 \mathrm{BaO} \cdot \mathrm{SiO}_{2}$, the samples were prepared by adding $\mathrm{BaCO}_{3}$ and silica gel to the dicalcium raw mix in the mole proportions of $\mathrm{BaO}$ and $\mathrm{SiO}_{2}$ of $2: 1$. Toropow and Konowalow [11] have reported that barium orthosilicate forms a complete solid solution series with calcium orthosilicate, $2 \mathrm{CaO} . \mathrm{SiO}_{2}$, basing their conclusions on measurements of refractive indices and density. The lowering of the $\beta \rightarrow \alpha$ temperature of inversion as obtained by heating curves (represented by crosses in fig. 8) confirms their work, since the temperature of this inversion continued to be lowered by all of the added increments of $2 \mathrm{BaO} . \mathrm{SiO}_{2}$ made in the present study. It was found also that a similar lowering was caused by the adding of $\mathrm{BaO}$ (see the curve through the open circles in fig. 8).

The existence of a solid solution series of the substitution type was indicated by the X-ray diffraction patterns of $\beta-2 \mathrm{CaO} . \mathrm{SiO}_{2}$ containing $2 \mathrm{BaO} . \mathrm{SiO}_{2}$. These patterns showed a slight shift of some of the lines from their normal position for $\beta-2 \mathrm{CaO} \cdot \mathrm{SiO}_{2}$.

The additions of $\mathrm{BaO}$, either as $\mathrm{BaO}$ or $2 \mathrm{BaO} \cdot \mathrm{SiO}_{2}$, did not prevent the $\beta \rightarrow \gamma$ inversion until the equivalent of 10 percent of $\mathrm{BaO}$ had been added (table 3 ).

\section{3. $\mathrm{Cr}_{2} \mathrm{O}_{3}$}

The temperature of the $\beta \rightarrow \alpha$ inversion of dicalcium silicate was lowered to about $1,400^{\circ} \mathrm{C}$ by $\mathrm{Cr}_{2} \mathrm{O}_{3}$ (fig. 8) and the limit of solubility in the $\alpha$ form, as indicated by the heating curves, was approximately 2.5 percent. Solid solution in the $\beta$ form, indicated by the green color of the crystals, the inhibition of the $\beta \rightarrow \gamma$ inversion, and the raising of the refractive indices [12] must be less than 2.5 percent as the inversion temperature is lowered by the addition to the solute.

\section{4. $\mathrm{V}_{2} \mathrm{O}_{5}, \mathrm{P}_{2} \mathrm{O}_{5}, \mathrm{~B}_{2} \mathrm{O}_{3}$, AND $\mathrm{Mn}_{2} \mathrm{O}_{3}$}

The oxides $\mathrm{V}_{2} \mathrm{O}_{5}$ and $\mathrm{P}_{2} \mathrm{O}_{5}$ (fig. 9) and $\mathrm{B}_{2} \mathrm{O}_{3}$ and $\mathrm{Mn}_{2} \mathrm{O}_{3}$ (fig. 10) resembled each other in their effects on dicalcium silicate. These oxides lowered the $\alpha \rightleftarrows \beta$ inversion temperature. They also prevented the $\beta \rightarrow \gamma$ inversion (dusting) and in this respect, resembled $\mathrm{Cr}_{2} \mathrm{O}_{3}$.

The heating curves of dicalcium silicate containing either $\mathrm{V}_{2} \mathrm{O}_{5}$, $\mathrm{P}_{2} \mathrm{O}_{5}, \mathrm{~B}_{2} \mathrm{O}_{3}$, or $\mathrm{Mn}_{2} \mathrm{O}_{3}$, were characterized by one or more heat effects in addition to that caused by the inversion. The inversion temperatures of preparations containing $\mathrm{V}_{2} \mathrm{O}_{5}$ or $\mathrm{P}_{2} \mathrm{O}_{5}$ were lowered continuously by further increments of these oxides after the appearance of heat effects at higher temperatures. Normally, heat effects occurring above the inversion temperature, where $\alpha-2 \mathrm{CaO} . \mathrm{SiO}_{2}$ is the stable form, would indicate that the limit of solubility of the added substance in this form of $2 \mathrm{CaO} . \mathrm{SiO}_{2}$ had been exceeded and further lowering of the $\alpha \rightleftarrows \beta$ inversion should not occur. The authors have not found a satisfactory explanation for the apparent contradiction in the cases of $\mathrm{V}_{2} \mathrm{O}_{5}$ and $\mathrm{P}_{2} \mathrm{O}_{5}$. Nevertheless, the first appearance of heat effect at temperatures above that of the $\alpha \rightleftarrows \beta$ inversion has been assumed to signify the limits of solubility. Therefore, from figures 9 and 10, the limits of solubility of $\mathrm{V}_{2} \mathrm{O}_{5}, \mathrm{P}_{2} \mathrm{O}_{5}, \mathrm{~B}_{2} \mathrm{O}_{3}$, and $\mathrm{Mn}_{2} \mathrm{O}_{3}$, in $2 \mathrm{CaO} . \mathrm{SiO}_{2}$ have been estimated not to exceed $0.5,1.0,8.0$, and 8.0 percent, respectively. 
That both $\mathrm{B}_{2} \mathrm{O}_{3}$ and $\mathrm{Mn}_{2} \mathrm{O}_{3}$ are soluble in $\beta-2 \mathrm{CaO} . \mathrm{SiO}_{2}$ are indicated by the changes they produce in the refractive index of $\beta-2 \mathrm{CaO} . \mathrm{SiO}_{2}$, by their prevention of the $\beta$ to $\gamma$ inversion, and,in the case of $\mathrm{Mn}_{2} \mathrm{O}_{3}$, the formation of colored crystals of $\beta-2 \mathrm{CaO} . \mathrm{SiO}_{2}$. The appearance of additional heat effects (fig. 10) at temperatures below the $\beta \rightarrow \alpha$ inversion, where $\beta-2 \mathrm{CaO} . \mathrm{SiO}_{2}$ is the stable form, indicates that the limit of solubility of $\mathrm{B}_{2} \mathrm{O}_{3}$ in $\beta-2 \mathrm{CaO} . \mathrm{SiO}_{2}$ does not exceed 4.00 percent. The additional heat effects were caused by the melting of the ternary eutectic $\left(2 \mathrm{CaO} . \mathrm{SiO}_{2}-\mathrm{CaO} . \mathrm{SiO}_{2}-2 \mathrm{CaO} . \mathrm{B}_{2} \mathrm{O}_{3}\right)$ at $1,118^{\circ} \mathrm{C}$ [13], and the disappearance of the phase $\mathrm{CaO} . \mathrm{SiO}_{2}$ at $1,176^{\circ} \mathrm{C}$.

A limit of solubility of $\mathrm{Mn}_{2} \mathrm{O}_{3}$ in $\beta-2 \mathrm{CaO} . \mathrm{SiO}_{2}$ of not exceeding 4.00 percent was indicated by the presence of an additional phase among the greenish crystals of a preparation of $\beta-2 \mathrm{CaO} . \mathrm{SiO}_{2}$ to which 4.00 percent of $\mathrm{Mn}_{2} \mathrm{O}_{3}$ had been added.

The present data indicate two minor changes in the ternary diagram of the sysem $\mathrm{CaO}-\mathrm{B}_{2} \mathrm{O}_{3}-\mathrm{SiO}_{2}$ as portrayed by Flint and Wells [13]. The solid-solution area shown in their report apparently should extend at least as far as the line joining $2 \mathrm{CaO} . \mathrm{SiO}_{2}$ and $\mathrm{B}_{2} \mathrm{O}_{3}$, and the boundary between $\alpha$ - and $\beta$-2 $\mathrm{CaO}^{-\mathrm{SiO}_{2}}$ should curve somewhat more abruptly so as to cross the $1,300^{\circ} \mathrm{C}$ isotherm at about the intersection with $2 \mathrm{CaO} \cdot \mathrm{SiO}_{2}-\mathrm{B}_{2} \mathrm{O}_{3}$ tieline.

\section{5. $\mathrm{Na}_{2} \mathrm{O}$ AND $\mathrm{K}_{2} \mathrm{O}$}

The alkalies, $\mathrm{Na}_{2} \mathrm{O}$ and $\mathrm{K}_{2} \mathrm{O}$, were somewhat volatile under the conditions encountered in preparing the samples and obtaining the heating and cooling curves. The points in figure 11 are based on the percentage of alkali calculated from chemical analyses of the mixtures after the experiments had been completed. The data for $\mathrm{K}_{2} \mathrm{O}$ are limited to a narrow range of composition because of the relatively large loss by volatilization. However, 0.6 percent of $\mathrm{K}_{2} \mathrm{O}$ lowered the temperature of the $\beta \rightarrow \alpha$ inversion of $2 \mathrm{CaO} . \mathrm{SiO}_{2}$ to $1,402^{\circ} \mathrm{C}$. It was found that $\mathrm{Na}_{2} \mathrm{O}$ lowered the temperature of the $\beta \rightarrow \alpha$ inversion to about $1,290^{\circ} \mathrm{C}$ where it became indistinguishable from another and unidentified heat effect. The limit of solubility of $\mathrm{Na}_{2} \mathrm{O}$ in $\alpha$ $2 \mathrm{CaO} . \mathrm{SiO}_{2}$ is uncertain but probably exceeds 1.3 percent. The limit of solubility in $\beta-2 \mathrm{CaO} . \mathrm{SiO}_{2}$ is less than 0.4 percent, as indicated by the appearance of the additional heat effect at $1,288^{\circ} \mathrm{C}$.

\section{X-RAY DIFFRACTION PATTERNS}

The X-ray diffraction patterns of samples containing $\mathrm{BaO}, \mathrm{P}_{2} \mathrm{O}_{5}$, $\mathrm{Na}_{2} \mathrm{O}$, and $\mathrm{K}_{2} \mathrm{O}$ showed slight shifts in certain lines of the X-ray pattern of $\beta-2 \mathrm{CaO} . \mathrm{SiO}_{2}$, indicating that these materials form solid solutions of the substitution type. Shifts in the lines were not observed in patterns of dicalcium silicate containing $\mathrm{Al}_{2} \mathrm{O}_{3}, \mathrm{TiO}_{2}, \mathrm{Cr}_{2} \mathrm{O}_{3}, \mathrm{~B}_{2} \mathrm{O}_{3}$, $\mathrm{Mn}_{2} \mathrm{O}_{3}$, or $\mathrm{V}_{2} \mathrm{O}_{5}$. Because the $\beta$ form of dicalcium silicate was not retained in quenched samples of the preparations to which had been added $\mathrm{MgO}, \mathrm{Fe}_{2} \mathrm{O}_{3}, \mathrm{CaO}$, or $\mathrm{SiO}_{2}, \mathrm{X}$-ray diffraction patterns were not prepared. Burdick [9] succeeded in preserving the $\beta$ form of $2 \mathrm{CaO} \cdot \mathrm{SiO}_{2}$ in a preparation containing $\mathrm{Fe}_{2} \mathrm{O}_{3}$ by heating and dehydrating a mixture of $\mathrm{Fe}_{2} \mathrm{O}_{3}$ and the dicalcium silicate hydrate, $10 \mathrm{CaO} .5 \mathrm{SiO}_{2} \cdot 6 \mathrm{H}_{2} \mathrm{O}$. The X-ray pattern of the resulting preparation showed a slight shift in the lines characterizing $\beta-2 \mathrm{CaO} . \mathrm{SiO}_{2}$, and there- 
fore confirmed the presence of a limited solid solution of $\mathrm{Fe}_{2} \mathrm{O}_{3}$ in dicalcium silicate.

\section{VIII. $\beta \rightarrow \gamma$ INVERSION OF $2 \mathrm{CaO} \cdot \mathrm{SiO}_{2}$}

The expansion accompanying the $\beta \rightarrow \gamma$ inversion of dicalcium silicate results in the crumbling to a fine powder, or "dusting," of portland cement clinker containing substantial quantities of unstabilized $\beta-2 \mathrm{CaO} . \mathrm{SiO}_{2}$. The inversion of even a moderate amount causes sufficient expansion to produce cracking or disintegration of material such as blast furnace slag and dolomitic refractories.

In the case of portland cement clinker the $\gamma$ form is undesirable since it has no hydraulic properties, and, consequently, does not contribute to the strength of the hardened cement, whereas $\beta$ dicalcium silicate is a valuable constituent because of its hydraulic properties.

It has been observed [4] that $\mathrm{Cr}_{2} \mathrm{O}_{3}, \mathrm{~B}_{2} \mathrm{O}_{3}, \mathrm{P}_{2} \mathrm{O}_{5}, \mathrm{~V}_{2} \mathrm{O}_{5}$, and $\mathrm{As}_{2} \mathrm{O}_{5}$ prevent the $\beta \rightarrow$ inversion when present in comparatively small amounts. These materials have been termed chemical inhibitors of "dusting", and $\mathrm{Mn}_{2} \mathrm{O}_{3}$ should be added to this list. Zerfoss and Davis [4] have explained that such inhibitors prevent the $\beta \rightarrow \gamma$ inversion by entering into solid solution with dicalcium silicate, and that other substances may prevent this inversion by physically restraining the particles from expanding, or by isolating the crystals of $\beta-2 \mathrm{CaO} . \mathrm{SiO}_{2}$ from points initiating the inversion. It is believed by many in the cement industry [14] that $\mathrm{Al}_{2} \mathrm{O}_{3}, \mathrm{MgO}, \mathrm{Fe}_{2} \mathrm{O}_{3}$, or any material which is present as glass, may prevent dusting.

\section{SUMMARY AND CONCLUSIONS}

Details were given of the application of differential heating and cooling curves to the determination of the temperature of the $\alpha \rightleftarrows \beta$ inversion of $2 \mathrm{CaO} . \mathrm{SiO}_{2}$, and to the measurement of limits of solid solution of $\mathrm{CaO}, \mathrm{SiO}_{2}, \mathrm{Al}_{2} \mathrm{O}_{3}, \mathrm{MgO}, \mathrm{Fe}_{2} \mathrm{O}_{3}, \mathrm{TiO}_{2}, \mathrm{CaF}_{2}, \mathrm{BaO}, \mathrm{Cr}_{2} \mathrm{O}_{3}$, $\mathrm{V}_{2} \mathrm{O}_{5}, \mathrm{P}_{2} \mathrm{O}_{5}, \mathrm{~B}_{2} \mathrm{O}_{3}, \mathrm{Mn}_{2} \mathrm{O}_{3}, \mathrm{Na}_{2} \mathrm{O}$, and $\mathrm{K}_{2} \mathrm{O}$ in dicalcium silicate.

It was found that the $\alpha \rightleftarrows \beta$ inversion temperature is sensitive to variations from the molar ratio $2 \mathrm{CaO}: \mathrm{SiO}_{2}$. By means of heating curves it was possible to observe not only the effects of chemically undetectible variations from the $2: 1$ molar ratio, but also the limits of solid solution of these oxides in $\alpha-2 \mathrm{CaO} . \mathrm{SiO}_{2}$, and the formation of additional crystalline phases.

As an increase in volume of about 10 percent accompanies the $\beta \rightarrow \gamma$ inversion of $2 \mathrm{CaO} . \mathrm{SiO}_{2}$, and causes the so-called "dusting" of dicalcium silicate and may result in a destructive expansion of materials in which it is an ingredient, the effectiveness of these oxides in preventing this inversion was studied. Also, because $\gamma-2 \mathrm{CaO} . \mathrm{SiO}_{2}$, in contrast with $\beta-2 \mathrm{CaO} . \mathrm{SiO}_{2}$, has no hydraulic properties, it is not desired in portland cement clinkers.

It was emphasized that lowering of temperature of the $\alpha \rightleftarrows \beta$ inversion indicated greater solubility of the added material in the alpha form of dicalcium silicate than in the beta, and that the limit of solubility in the alpha form had been reached when the addition of more of the solute caused no further change in the temperature of the $\alpha \rightleftarrows \beta$ inversion.

The limits of solubility of $\mathrm{Al}_{2} \mathrm{O}_{3}, \mathrm{MgO}, \mathrm{Fe}_{2} \mathrm{O}_{3}$, and $\mathrm{TiO}_{2}$ in $\alpha-2 \mathrm{CaO}$.$\mathrm{SiO}_{2}$ were estimated to be $0.5,0.5,1.0,0.7$, and 1.0 percent, respec$680952-46-4$ 
tively. The limits of solubility in $\beta-2 \mathrm{CaO} . \mathrm{SiO}_{2}$ must be less, since the temperature of the inversion was lowered. None of the materials prevented dusting.

The limit of solubility of $\mathrm{BaO}^{\prime}$ or $2 \mathrm{BaO} \cdot \mathrm{SiO}_{2}$ in dicalcium silicate was not reached. Other investigators have reported that $2 \mathrm{CaO} . \mathrm{SiO}_{2}$ and $2 \mathrm{BaO} . \mathrm{SiO}_{2}$ form a complete solid solution series and the data obtained in this investigation (including $\mathrm{X}$-ray diffraction patterns of $\beta-2 \mathrm{CaO} . \mathrm{SiO}_{2}$ containing $2 \mathrm{BaO} . \mathrm{SiO}_{2}$ ) support that conclusion in the range of compositions studied. The additions of $\mathrm{BaO}$, either as $\mathrm{BaO}$ or $2 \mathrm{BaO} . \mathrm{SiO}_{2}$, did not prevent the $\beta \rightarrow \gamma$ inversion (and "dusting") until the equivalent of 10 percent of $\mathrm{BaO}$ had been added.

The limits of solubility of $\mathrm{Cr}_{2} \mathrm{O}_{3}, \mathrm{~V}_{2} \mathrm{O}_{5}, \mathrm{P}_{2} \mathrm{O}_{5}, \mathrm{~B}_{2} \mathrm{O}_{3}$, and $\mathrm{Mn}_{2} \mathrm{O}_{3}$ were estimated to be $2.5,0.5,1.0,8.0$, and 8.0 percent, respectively. Preparations containing these materials gave evidences of their solubility in $\beta-2 \mathrm{CaO} . \mathrm{SiO}_{2}$ by changes in color or refractive index, and the absence of dusting. The limits of solubility of both $\mathrm{B}_{2} \mathrm{O}_{3}$ and $\mathrm{Mn}_{2} \mathrm{O}_{3}$ in $\beta-2 \mathrm{CaO} . \mathrm{SiO}_{2}$ were estimated not to exceed 4.0 percent.

The volatility of the alkalies, $\mathrm{Na}_{2} \mathrm{O}$ and $\mathrm{K}_{2} \mathrm{O}$, hindered the study of their effects on $2 \mathrm{CaO} \cdot \mathrm{SiO}_{2}$ and no estimate of the solubility of $\mathrm{K}_{2} \mathrm{O}$ was made. It was estimated that the limit of the solubility of $\mathrm{Na}_{2} \mathrm{O}$ in $\alpha-2 \mathrm{CaO} . \mathrm{SiO}_{2}$ was slightly in excess of 1.3 percent, and that its solubility in the $\beta$ form did not exceed 0.4 percent.

Limiting values of the solubility of $\mathrm{TiO}_{2}, \mathrm{~B}_{2} \mathrm{O}_{3}, \mathrm{~V}_{2} \mathrm{O}_{5}, \mathrm{Mn}_{2} \mathrm{O}_{3}$, or $\mathrm{Na}_{2} \mathrm{O}$ in $\beta-2 \mathrm{CaO} . \mathrm{SiO}_{2}$ were shown by the presence of other phases in addition to $2 \mathrm{CaO} . \mathrm{SiO}_{2}$. The additional phase was observed microscopically for $\mathrm{Mn}_{2} \mathrm{O}_{3}$; with the other oxides by inflections on heating and cooling curves in addition to the inflection caused by the $\alpha \rightleftarrows \beta$ inversion of dicalcium silicate.

This investigation has shown that most of the common oxides change the temperature of the $\alpha \rightleftarrows \beta$ inversion of $2 \mathrm{CaO} . \mathrm{SiO}_{2}$ and that $\mathrm{Mn}_{2} \mathrm{O}_{3}$ should be added to the list of known chemical inhibitors that prevent dusting.

\section{REFERENCES}

[1] T. W. Parker and J. F. Ryder, J. Iron Steel Inst. (London) 146, 21 P (1942).

[2] G. E. Seil and staff, J. Am. Ceram. Soc. 20, 1 (1941).

[3] G. A. Rankin and F. E. Wright, Am. J. Sci. [4] 29, 1 (1915).

[4] S. Zerfoss and H. M. Davis, J. Am. Ceram. Soc. 26, 302 (1943).

[5] E. S. Newman, J. Research NBS 27, 191 (1941) RP1413.

[6] W. P. White, Am. J. Sci. [4] 28, 453 (1909).

[7] H. S. Roberts, J. Opt. Soc. Am. \& Rev. Sci. Inst. 11, 171 (1925).

[8] W. F. Roeser and H. T. Wensel, BS J. Research 10, 275 (1933) RP530.

[9] M. D. Burdick, J. Research NBS 25, 475 (1940) RP1340.

[10] S. Zerfoss, Thesis. The Pennsylvania State College (1942).

[11] N. A. Toropow and P. F. Konowalow, Compt. rend. acad. sci. U. R. S. S. 22, 663 (1938).

[12] P. H. Bates and A. A. Klein, BS Tech. Pap. 78 (1917).

[13] E. P. Flint and L. S. Wells, J. Research NBS 17, 727 (1936) RP941.

[14] R. H. Bogue, private communication.

Washington, September 28, 1945. 